Swarthmore College

Works

6-1-2011

\title{
Fertilization Narratives In The Art Of Gustav Klimt, Diego Rivera And Frida Kahlo: Repression, Domination And Eros Among Cells
}

\author{
Scott F. Gilbert \\ Swarthmore College, sgilber1@swarthmore.edu
}

S. Brauckmann

Follow this and additional works at: https://works.swarthmore.edu/fac-biology

Part of the Biology Commons

Let us know how access to these works benefits you

\section{Recommended Citation}

Scott F. Gilbert and S. Brauckmann. (2011). "Fertilization Narratives In The Art Of Gustav Klimt, Diego Rivera And Frida Kahlo: Repression, Domination And Eros Among Cells". Leonardo. Volume 44, Issue 3. 221-227.

https://works.swarthmore.edu/fac-biology/158

This work is brought to you for free by Swarthmore College Libraries' Works. It has been accepted for inclusion in Biology Faculty Works by an authorized administrator of Works. For more information, please contact myworks@swarthmore.edu. 


\section{PROJECT MUSE*}

Fertilization Narratives in the Art of Gustav Klimt, Diego Rivera and Frida Kahlo: Repression, Domination and Eros among Cells

Scott F. Gilbert, Sabıne Brauckmann

Leonardo, Volume 44, Number 3, June 2011, pp. 221-227 (Article)

Published by The MIT Press

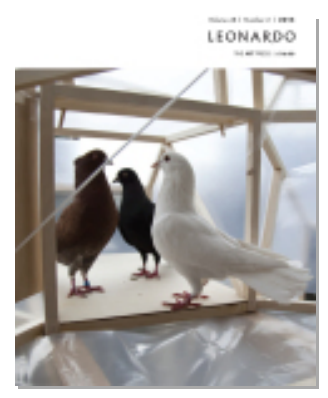

$\Rightarrow$ For additional information about this article

http://muse.jhu.edu/journals/len/summary/v044/44.3.gilbert.html 
H IS T O R I CA L PER S PEC TIVE

\section{Fertilization Narratives in the Art of Gustav Klimt, Diego Rivera and Frida Kahlo: Repression, Domination and Eros among Cells}

\author{
Scott F. Gilbert and \\ Sabine Brauckmann
}

A B S T R A C T

$F_{\text {ertilization narratives are }}$ powerful biological stories that can be used for social ends, and 20th-century artists have used fertilization-based imagery to convey political and social ideas. In Danae, Gustav Klimt used an esoteric stage of early human embryos to indicate successful fertilization and the inability of government repression to stifle creativity. In Man, Controller of the Universe, Diego Rivera painted a mural of a man controlling an ovulating ovary, depicting Trotsky's view that society will rationally regulate human fertilization. His former wife, Frida Kahlo, refuted this view in Moses: Nucleus of Creation, wherein she painted images of fertilization and embryo formation as the ultimate acts of erotic consummation and generation. tic interpretation. Flannery [1] has documented that the scientific construction of a cell is an artistic process and that there is no such thing as an uninterpreted cell. Stains, instruments and the wavelengths of light allow us to see certain things and not others; and the representation of cells is an ongoing process of data accumulation and interpretation. Moreover, when pictures of cells become widespread throughout society, they, too, become cultural artifacts and can be used as symbols, indices and icons [2-4].

Gustav Klimt (1862-1928), Diego Rivera (1886-1957) and Frida Kahlo (1907-1954), three artists whose art and reputations often centered on their sexual and political lives, each depicted cellular events associated with fertilization and pregnancy. Klimt used an early embryonic stage of human development, the blastocyst, to indicate the successful fertilization of Danae and the victory of creativity over repression. Rivera used the ovulating ovarian follicle as an icon of man's (gendered) control over nature. And Kahlo saw in the union of sperm and egg the central act of love between two individuals.

\section{KLIMT'S DANAE: A SUCCESSFUl FERTILIZATION OF ART AND SCIENCE}

Gustav Klimt's Danae is a masterpiece of Secessionist art, representing the complex interplay of masculinity and femininity, freedom and repression, classicism and eroticism that characterized Freud's Vienna before the Great War. It is also a fascinating instance of interplay between science and art. In Danae, Klimt presented a stylized depiction of the mammalian blastocyst and used this early embryonic structure to show the victory of creativity over repression.

This 1907 oil painting (Fig. 1) depicts the impregnation of the beautiful Danae by Zeus, who appears as a shower of golden coins/rain flowing between her legs. Danae's father,

Scott F. Gilbert, (educator), Department of Biology, Swarthmore College, Swarthmore, PA 19081, U.S.A.; University of Helsinki, Finland. E-mail: <sgilber1@swarthmore.edu>.

Sabine Brauckmann, (researcher), Science Studies, University of Tartu, Science Center Tartu University Library, Struve 1, 50091 Tartu, Estonia; EHI Estonian Humanities Institute, Tallinn University, Estonia. E-mail: <sabine@ut.ee>.

King Akrisios of Argos, fearing the prophecy that he would be killed by his grandson, had locked his daughter in a tower to ensure that no pregnancy could occur. Art historians have interpreted the rectangle near Danae's genitals to be the symbol of Zeus's masculinity.

Indeed, Klimt used the rectangle as a phallic symbol in other paintings during this time, including Lebensbaum (1905-1909) and Der Kuss (1907-1908). Certainly rectangles were part of Klimt's sexual vocabulary.

Fig. 1. Gustav Klimt, Danae, oil on canvas; $77 \times 83 \mathrm{~cm}$, 1907. Private collection. The rectangle on the left represents Zeus, while the circular biomorphic forms in the purple robe are interpreted to be blastocysts [73]. Danae had been imprisoned to prevent her becoming pregnant. Zeus, however, visits Danae, and the prophecy is fulfilled. (Danae's son, Perseus, does accidentally kill Akrisios with a discus.) The dating of the painting is not exact [74].

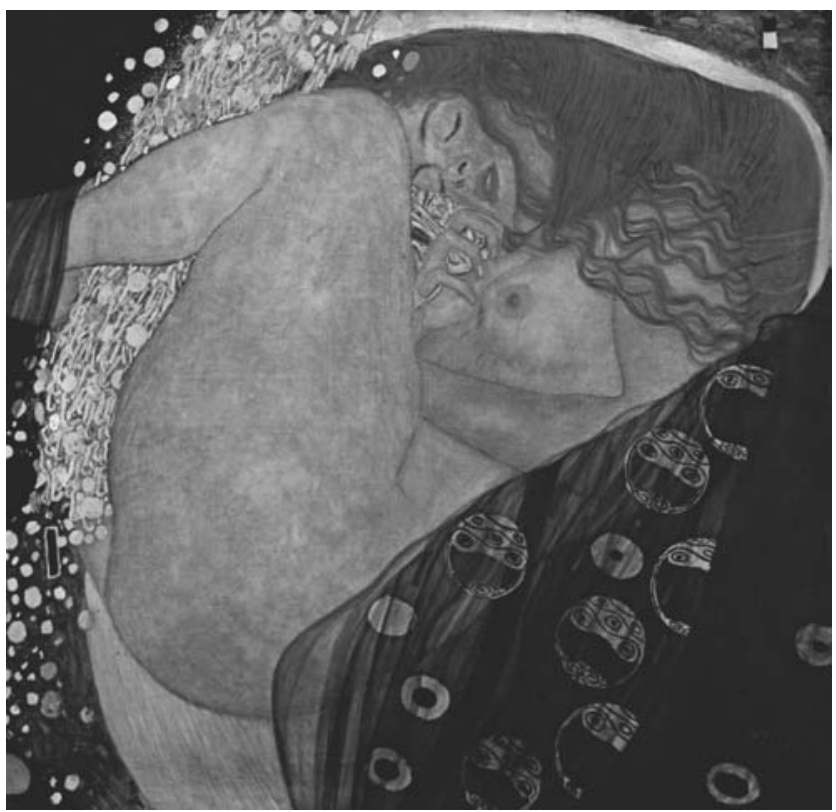



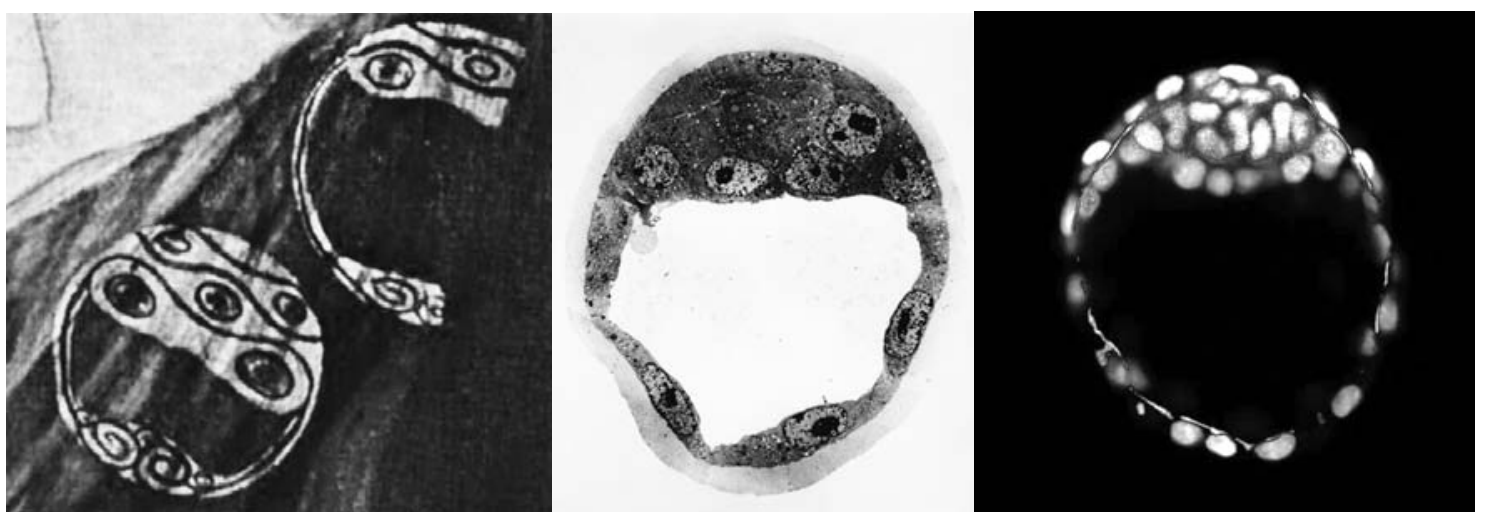

Fig. 2. Figures in Klimt's Danae (a) compared with photographs of mouse blastocysts seen by electron microscopy (b) and light microscopy (c). ([b] @) Thomas Ducibella [75]; [c] @ Janet Rossant [76].)

What, however, are the prominent circular biomorphic forms in Danae's purple gown and why are they in the forefront of the painting? Art historians have assigned to these "gold filigree disks" a vague Mycenaean character [5] or a purely ornamental function, describing them, for example, as "ovaloid shapes between gentle wave-like lines" $[6,7]$. We believe that these biomorphic forms are indeed embryonic cells, specifically mammalian blastocysts (Fig. 2). This interpretation would complement the idea that Klimt depicted Zeus's golden shower as "chromosome-like biological shapes" [8] or "gilded spermatozoa" [9]. Moreover, art historians have noticed that the nude Danae is confined to a "closed embryonic oval" [10], referencing the womb, and we propose that Klimt was artistically depicting blastocysts inside Danae's uterus, indicating the pregnancy that Akrisios so feared.

The blastocyst, first described by August Rauber and Rudolph Leukart in the 1880 s, is a diagnostic stage of mammalian development [11]. It is a mass of cells characterized by (a) an outer ring of cells (the trophoblast) that will adhere to the uterus and form the fetal portion of the placenta; (b) the inner cell mass, which adheres to one pole of the trophoblast and is the source of the embryonic stem cells that generate the fetus; and (c) a fluid-filled cavity, the blastocoel. To an embryologist, these figures in Danae's robe certainly look like a Secessionist rendering of a blastocyst.

Blastocysts are not exactly part of public knowledge then or now. Did Klimt, then, really know about the blastocyst? He could readily have received information about this early embryonic form from two societal contacts at the Zuckerkandl salon: Emil Zuckerkandl (18491910), who was the leading anatomist of Vienna, and Hans Przibram (18741944/5), a renowned embryologist who was founder and director of the Vivarium in Vienna's Prater Park.

Emil Zuckerkandl was the chair of Anatomy and Pathology at the University of Vienna. He not only took clinical and comparative anatomy to new heights [12-14] but also was an exceptional teacher, who accompanied his lectures with excellently drawn and accurate illustrations $[15,16]$. Socially liberal, Zuckerkandl was professionally and personally involved in promoting university education for women and actively participated in explaining scientific research to society $[17,18]$.

His wife, Bertha Szeps-Zuckerkandl (1864-1945), one of the most remarkable personalities of Viennese society during the last decades of the AustroHungarian Empire, was a novelist, journalist and writer; but her passion was for modern art. Her salon became a meeting place for artists, literati and academics, and her circle of friends included $\mathrm{Au}-$ guste Rodin, Josef Hoffmann, Gustav Mahler, Max Reinhardt, Hans Przibram and in particular Gustav Klimt, whom she openly supported against his critics [19-21]. Her 1905 interview with Klimt concerning the scandal of his murals at the University of Vienna (which the Ministry of Education, on grounds of morality, refused to exhibit $[22,23]$ ) remained his major statement about license and artistic freedom [24,25].

Szeps's marriage to Zuckerkandl opened another venue for her-namely, the world of science. In her memoirs she wrote,

Stimulated by Gustav Klimt, my husband started to hold scientific evening lectures for artists. On these evenings, the Anatomical Institute in the Währingerstrasse was filled with a mood that you meet else- where at sensational theatre premieres. The auditorium was densely packed. Painters, novelists, and musicians were there, or sent representatives [26].

There (more accurately, in the "Volksheim" Adult Evening Center in Ottakring [27]), her academically robed husband thrilled his audience by showing, through projected slides, the microscopic wonders of blood vessels, the epidermis, arteries and brain neurons. Szeps-Zuckerkandl claimed explicitly that Klimt's palette was enriched and influenced by the microscopic anatomy shown at Emil Zuckerkandl's evening lectures ("Gerade Klimts Palette ist von diesem Anreiz der Sinne bereichert und beeinflusst worden" [28]).

If Klimt had wanted specific knowledge of embryos, there was also another member of the Zuckerkandl salon to turn to: Hans Przibram. Przibram (1874-1944/5; he died in Theresienstadt concentration camp) was founder and director of Vienna's Prater Vivarium, one of the leading developmental biology research institutes in Europe $[29,30]$. He was a leading researcher on the laws of growth and was one of the first experimental embryologists to use chemistry, biomechanics and mathematics in his explanations. He was also an accomplished artist and writer. According to Sander Gliboff, "Przibram was noted for his artwork, and his drawings were exhibited at the Secession, Vienna's center for Standstill art, and printed in the Secession journal: Ver Sacrum" [31]. The contact between artist and painter was so close that musicologist Anna Harrell Celesta writes, "One of Klimt's most loyal assistants, an amateur painter named Hans Leo Przibram (1874-1944), was simultaneously making a name for himself as a biologist" [32]. Thus, Vienna's leading embryologist, who, like other contem- 
porary embryologists, had depicted blastocysts in his textbooks [33], was also a Secessionist artist, art critic and friend of Klimt.

Thus, if Klimt wanted to depict the successful impregnation of Danae by representing an early embryonic stage, he would have had ready access to this type of knowledge. Blastocysts would have been an exciting, esoteric and accurate way of showing the successful result of Zeus's visit to the imprisoned princess. This victory of creativity over a repressive ruler was most likely the subtext of this painting, for Klimt had just been involved in a series of censorship battles, especially those concerning the University murals. Conception, that archetypal creative act King Akrisios so feared, has happened, and the representation of Zeus on the left side (the rectangle and golden stream) is balanced on the right side by the blastocysts embedding into the purple lining of Danae's gown. Danae represents not only the successful mating of Zeus and Danae but also the circumvention of repression by creativity and the successful marriage of science and art in fin-de-siècle Vienna.

\section{DIEGO RIVERA'S MAN AT THE CROSSROADS: CELLS OF THE SOCIALIST UTOPIA}

Diego Rivera (1886-1957) also used the control of sexual reproduction as a theme in one of his major murals, and here, too, a microscopic image of human biology is used in the service of art. However, unlike Klimt's stylized depiction of the blastocyst, Rivera's painting of human ovulation is a direct borrowing of an icon from medical textbooks.

In 1932, Diego Rivera was commissioned by Nelson Rockefeller to paint a mural for the ground floor of the RCA Building in Rockefeller Center. It was to be, in Rockefeller's words, "Man at the Crossroads Looking with Hope and High Vision to the Choosing of a New and Better Future." With the help of six assistants, Rivera started working on the 63-footwide mural in March 1933. However, the Rockefeller patrons were neither pleased nor amused by the Communist nature of the painting. May Day parades and Lenin among the workers were not scenes favored by America's predominant family of capitalists. Therefore, on 22 May
1933, Rivera was paid in full and barred from the premises; and on the night of 9 February 1934, workers with axes and hammers destroyed the mural. The mural, however, was reconstructed that year by Rivera and his assistants in the Palace de Bellas Ares in Mexico City, where its title became Man, Controller of the Universe (or Man in the Time Machine). In Man, Controller of the Universe, Rivera added the image of his friend, the Communist Leon Trotsky, whom he would soon help to receive asylum in Mexico. Trotsky and his wife lived in the house of Frida Kahlo and Diego Rivera until shortly before the time he was assassinated [34-36].

In the center of the painting is a commanding presence, Man, the Controller of the Universe (Fig. 3). His gloved hands are on buttons and levers controlling heavy industrial machinery. A third hand, indeed a phallic hand, reaches out to grasp a ball that appears to be a control panel. On the top of the ball are engraved dials, and in the center of the ball is a dividing cell in mitotic metaphase.

This man at the crossroads is physically on the intersection of two diagonal lines, each representing that which he

Fig. 3. Diego Rivera, Man, Controller of the Universe, fresco mural, $4.85 \times 11.45$ m, 1934, detail. Palacio de Bellas Artes, Mexico City. (๔) 2011 Banco De Mexico Diego Rivera Frida Kahlo Museums Trust, Mexico, D.F.; Artists Rights Society [ARS], New York)

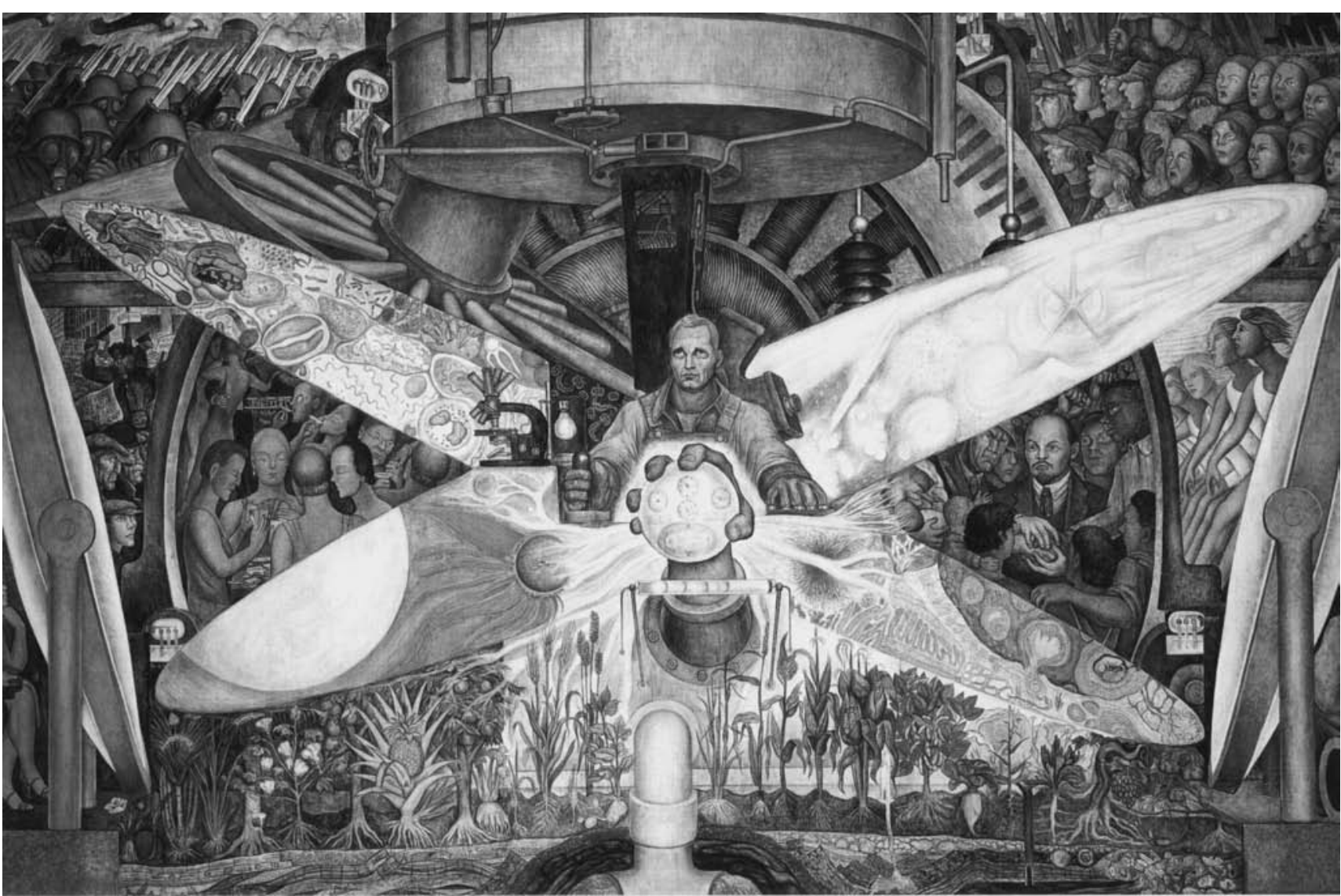




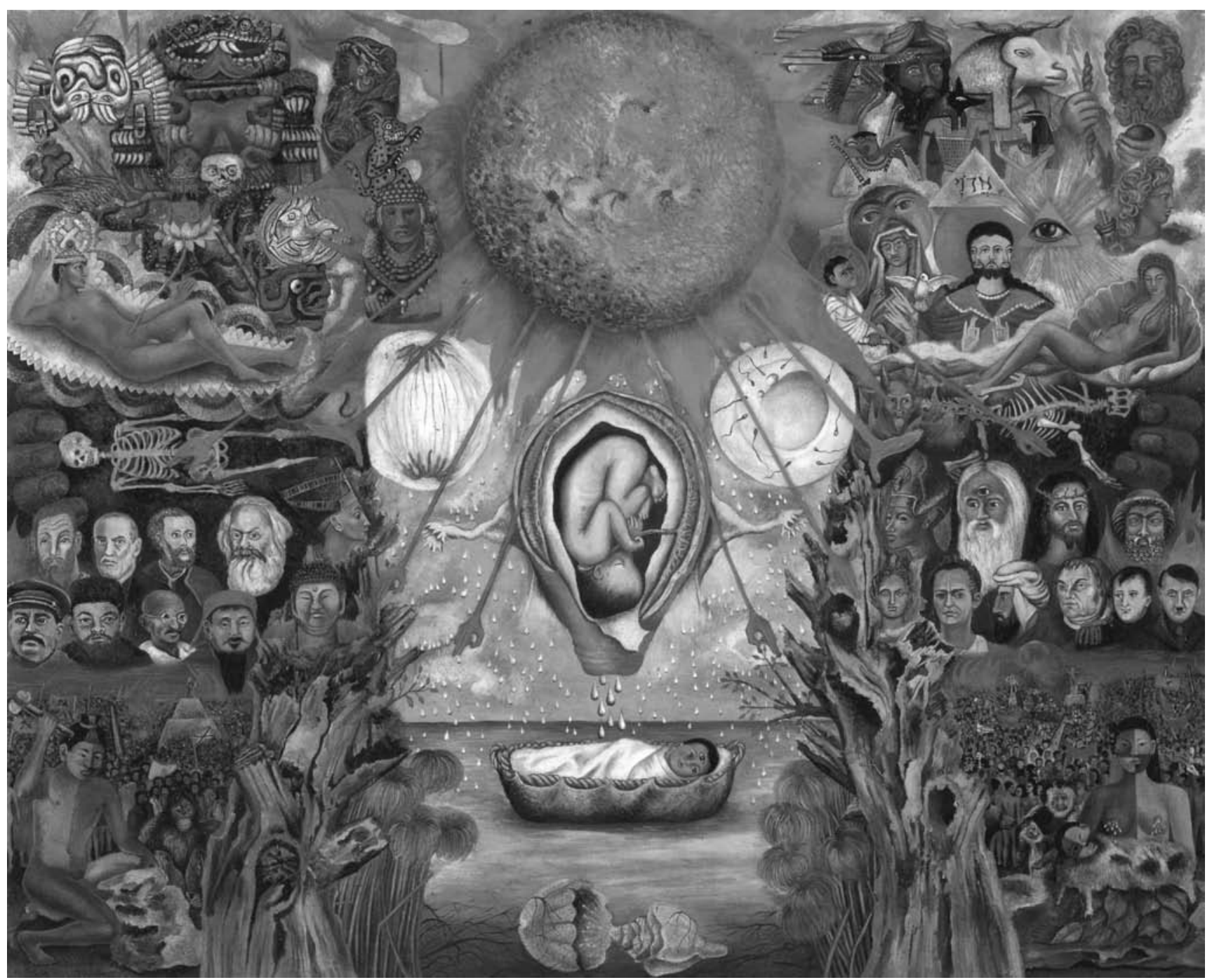

Fig. 4. Frida Kahlo, Moses (The Nucleus of Creation), oil on masonite, $61 \times 75.6 \mathrm{~cm}, 1945$. Private collection, Texas. This painting is not only an interpretation of Freud's Moses and Monotheism but also a rebuttal of the masculine view of the world in Diego Rivera's Man, Controller of the Universe. (@ 2011 Banco De Mexico Diego Rivera Frida Kahlo Museums Trust, Mexico, D.F.; Artists Rights Society [ARS], New York)

controls. On one diagonal line are the forces of the physical universe. On the other line are the elements of the biological world. On the left side of this diagonal are cells. These are not abstract cells but cells as they appear in bacteriology textbooks. These are cells from the heroic age of microbiology. Strings of rod-shaped bacteria are shown being digested within these immune system cells $[37,38]$. These images would indicate man's growing control over infectious disease. Looking at the right side of the diagonal, however, one sees a different group of cells. This biological form is also derived from a textbook illustration. It is the lower portion of the iconic clock face representation of mammalian ovulation. In this depiction, the maturation of the ovarian follicle is shown in a circular fashion, showing the egg developing from early follicle through ovulation into the hormone-secreting corpus luteum as it proceeds around the periphery of the ovary. This was the depiction of ovulation pioneered in the textbooks of Bradley Patten $[39,40]$, which has become the normative way of portraying these events [41]. The inclusion of a ripe ovum being ejected from its follicle at the moment of ovulation (a rare event but one illustrated by Patten and others) also demonstrates that this is from a textbook illustration. In Rivera's mural, the ovarian oocyte is seen in two stages of development, culminating in the ruptured follicle and the expulsion of the matured egg into the oviducts. Yes, the mural says, humans will control fertility, too.

Indeed, fertility control and eugenics (the two ideas were merged during the first half of the 20th century) was a major goal of the Rockefeller Foundation, and the Rockefellers have had a major role in supporting birth control in the United States [42]. Moreover, the domination of nature and fertility by technology was a locus where the interests of capitalists and communists converged. The mural is an almost perfect artistic reflection of the words written by Rivera's friend Trotsky: "The proper goal of communism is the domination of nature by technology and the domination of technology by planning, so that raw materials of nature will yield to mankind all that it needs and more besides" [43].

Trotsky specifically extended this control to fertility. In his famous work Literature and Revolution, he prophesied that man "will become the object of the most complicated methods of artificial selection and psycho-physical training. This is entirely in accord with evolution" [44] Also, in 1934, just as Diego Rivera was finishing his mural, Trotsky predicted, 
"You Americans, after taking a firm grip on your economic machinery and your culture, will apply genuine scientific methods to the problem of eugenics" [45].

Thus Diego Rivera employed textbook images of biology to demonstrate the new powers that science had given humankind to rid the world of infectious disease and to control human reproduction. Guided by Marx, Lenin, Trotsky and Darwin (whose images are in the mural), Rivera saw man at the crossroads entering a wonderful new age of control over disease and the scientific planning of the human race.

\section{MOSES OR THE NUCLEUS OF CREATION: FRIDA KAHLO'S UTERINE UNIVERSE}

Frida Kahlo was an artist obsessed with anatomy and development. Her desire to be a physician and her training as a premedical student are reflected in numerous morphologically detailed depictions of internal human anatomy [46,47]. In My Nurse and I, Kahlo presents the breasts of her Mexican wet-nurse in such a way as to show the milk ducts and mammary lobes. In Henry Ford Hospital, Kahlo became probably the first artist to represent a miscarriage (her own). There is no problem in understanding where Kahlo obtained her knowledge of embryology. Even after her medical studies, she kept in her house a "large lithograph depicting fertilization, embryonic development, and birth." Rosenzweig and Rosenzweig note that this is "undoubtedly a reference she consulted when painting many of her works" [48].

Two paintings that highlight developmental biology are Family Tree: My Grandparents, My Parents and I (1936) and Moses (1945). In Family Tree, Kahlo presents herself in self-portraits: (1) as a naked girl in the Blue Room; (2) as a fetus connected to her bridal mother by an umbilical cord; and (3) as an egg being fertilized by her father's sperm. In this last image, the sperm is seen entering the egg close to the egg nucleus with which it will merge. The presence of the zona pellucida and corona radiata around the egg shows that this is from a textbook illustration.

Kahlo's Moses (Fig. 4) brings us once again to the arts and sciences of $\mathrm{Vi}$ enna, for this is Kahlo's interpretation of Freud's Moses and Monotheism (1939), bringing the birth of Moses under the glowing rays of a scientifically accurate and actively energizing solar disc. It is also a rebuttal of her ex-husband's idea of Man the Controller. The central panel of this tripartite painting shows the embryology of the waterborne Moses, the fertilization event at the right, the successful fertilization shown by the dividing cell at the left and the fetus in the center. As Herrera has noted, the organization of the painting resembles "the anatomy of the pelvic region" and "Moses' birth is situated, quite appropriately, in the middle" [49].

In Moses, Kahlo provides the female response to Rivera's masculine universe. If Rivera paints Man, the Controller of the Universe, Kahlo is painting Woman: Creator of Life. The subtitle of the painting is The Nucleus of Creation. If Rivera's mural has a phallic arm controlling nature, then Kahlo's entire image can be viewed from afar as the universe as a uterus (the two reclining nudes forming the oviducts) about to give birth. As in Rivera's mural, there is a portrait gallery of famous individuals; but this is a painting where woman's fertility is the center of the universe. Indeed, Kahlo makes this clear in her diary accounts and her lecture on this painting [50-52]. The sun, which was one of those elements in Rivera's diagonals, is now a central element, the "creator and reproducer of life." The dividing cell, which had been engraved on the control panel of the controlling man, is now an active living agent. Like Klimt, she views the stages of cell division as proof that fertilization has succeeded. "On either side of the child," Kahlo explained in her lecture, "I put the elements of his creation, the fertilized ovum and cellular division." Moreover, Kahlo continues, Moses's basket is itself a womb (i.e. a womb within the womb), and the river in which this ark floats "signifies the maternal source in the birth of a child" [53]. As Bakewell [54] observed, the concentration on the vagina as an orifice of going out, not only of coming in, is also the subject of Kahlo's My Birth (1932), as well as the horrific element in her impalement by a metal rod at age 18 .

Kahlo's female universe is not a passive world but a world of female generative power. For Kahlo, fertilization is the symbol for ultimate love and the one single law-life itself. "Everything moves according to one law-life. . . . All is all and one. Anguish and pain, pleasure and death, are nothing but a process in order to exist. ... Universes and universal cells" [55]. The sperm and egg are these universal cells of creation and procreation. The sperm and egg are, as biologist F.R. Lillie claimed, "single cells, each on the point of death; but by their union a rejuvenated individual is formed, which constitutes a link in the eternal process of Life" $[56,57]$. The universe and universal cells.

\section{CODA}

The cell is both a biological entity and a cultural artifact [58,59], and art and science interact in its interpretation. Artistic conventions are used to render living and stained cells as textbook representations [60-62], and artists reinterpret these textbook illustrations that have become part of our cultural matrix. The "cell," as well as the "sperm" and "egg," microscopic entities though they are, have become part of our cultural context thanks to their renderings in textbooks and popular culture. Thus it should not be surprising that not only Klimt, Rivera and Kahlo, but also Max Ernst [63], Odilon Redon [64], Wassily Kandinsky [65], Paul Klee, Peter Randall-Page [66] and Edvard Munch [67] have referenced cells in their artwork.

In particular, the sperm and the egg are continually being re-interpreted according to political norms and aspirations. The collective term for these sex cells, gamete, comes from the Greek gamos (marriage), and there is a microcosm/ macrocosm relationship between the union of these sex cells and the union of men and women. The Biology and Gender Study Group [68,69] and Emily Martin [70] have shown that fertilization narratives model the expected interactions of men and women and that as courtship models changed, so did the scientific stories of sperm and egg. So it should not be surprising to see fertilization stories used in art as well.

As we have seen, Klimt, Kahlo and Rivera each took textbook representations of cells and used them as emblems of a larger reality. Klimt used blastocysts to show the victory of creativity over repression; Rivera painted ovarian follicles to show the victory of man over the forces of nature and procreation; and Kahlo employed fertilization and later development to show the act of ultimate love and the continuation of life. Interestingly, although these three paintings span a 50-year period and thousands of miles, the social interactions between scientists, physicians and avant-garde artists in the capital and Catholic cities of Mexico and Austria may have been very similar and especially conducive to the portrayal of scientific objects in art. Coomaraswamy claimed that a "three-fold path" of fertility, eroticism and endurance mediates natural objects into art [71,72]. This may also be true for the mediation of scien- 
tific representations of natural objects into art, for these qualities are certainly seen in the presentation of cells by Klimt, Rivera and Kahlo.

\section{Acknowledgments}

Scott Gilbert is supported by the U.S. National Science Foundation and the Academy of Finland. The research of Sabine Brauckmann was financially supported by a Basic Research Grant PPIRT08907 of the Estonian Ministry of Education and Research and the University of Tartu (Estonia). We would like to thank Stacy Bomento for her administrative help.

\section{References and Notes}

Unedited references as provided by the authors.

1. Flannery, M.C. "Images of the cell in twentieth century art and science." Leonardo 31, No. 3, 195-204 (1998).

2. Flannery [1].

3. Gilbert, S.F., Howes-Mischel, R. "Show Me You Original Face before You Were Born: The Convergence of Public Fetuses and Sacred DNA." Histor and Philosophy of the Life Sciences 26, 377-394 (2004)

4. Gilbert, S.F. (1988). "Cellular Politics: Just, Goldschmidt, and the attempts to reconcile embryology and genetics," in The American Development of Biology (ed. R. Rainger, K. Benson, J. Maienschein) University of Pennsylvania Press, Philadelphia. pp. 311-346.

5. Florman, L. "Gustav Klimt and the Precedent of Ancient Greece." Art Bulletin 72, 310-326 (1990).

6. Dean, C. Klimt. London: Phaidon (2003).

7. Wagner, M. Gustav Klimts verruchtes Ornament In Die weibliche und die männliche Linie. Das imaginär Geschlecht der modernen Kunst von Klimt bis Mondria (S. Deicher, ed.), pp. 27-50. Berlin: Reimer (1993).

8. Schorske, C.E. Fin-de-Siècle Vienna. Politics and Culture. New York: Alfred A. Knopf. p. 272 (1980)

9. Néret, G. Klimt. Köln: Taschen Verlag. p. 64 (2006)

10. Hoffmann, W. Gustar Klimt und die Wiener Jahrhundertwende. Salzburg: Verlag Galerie Wel Jahrhundertwend
(1970/2008).

11. Gilbert, S.F. Developmental Biology. Eighth ed. Sinauer Associates, Sunderland, MA (2006)

12. Ober, W.B. Emil Zuckerkandl and his delightfu little organ. In Pathology Annual (Sheldon C. Sommers, ed.) Vol. 18, Pt. 1, pp. 103-119 (1983).

13. Shoja, M.M., Tubbs, R.S., Loukas, M., Shokouhi, G., Oakes, W.J. Emil Zuckerkandl (1849-1910): Anatomist and pathologist. Annals of Anatomy 190, 33-36 (2008).

14. Zuckerkandl, E. Normale und pathologische Anato mie der Nasenhöhle und ihrer pneumatischen Anhänge. 2 Bde., Wien: W. Braumüller (French translation: Anatomie normale et pathologique des fosses nasales et de leurs annexes pneumatiques, 1895 (1882/1892).

15. Tandler, J. Emil Zuckerkandl. In Die Feierliche Inauguration des Rektors der Wiener Universität für das Studienjahr 1910/11, am 20. Oktober 1910, pp. 39-59 Studienjahr 1910/11, am 20. Oktober 1910, pp. 39-52
(obituary). Wien: Selbstverlag der K.K. Universitä (1910).

16. Lesky, E. Die Wiener medizinische Schule im 19. Jahr hundert, Graz-Köln: Böhlau Verlag (1965).

17. Felt, U. 1996. Öffentliche Wissenschaft: Zur Beziehung von Naturwissenschaften und Gesellschaft in Wien von der Jahrhundertwende bis zum Ende der ersten Republik. ÖZG 7: 45-66.

18. Hofer, V. (2002). Rudolf Goldscheid, Paul Kam- merer und die Biologen des Prater-Vivariums in de liberalen Volksbildung der Wiener Moderne. In Wissenschaft, Politik und Offentlichkeit (M. Ash \& C. Stifter, eds), pp. 149-184. Wien: Facultas Verlags- und Buchhandels AG WUV-Universitätsverlag (2002).

19. Redi, R. Bertha Zuckerkandl und die Wiener Gesellschaft. Ein Beitrag zur österreichischen Kunst- und Gesellschaftskritik (Ph.D. diss., University of Vienna) (1979)

20. Wagener, M.L. Berta Zuckerkandl. European His tory Quarterly 12, 425-444 (1982).

21. Brandstätter, Christian. Gustav Klimt und die Frauen. Wien: Brandstätter (1994).

22. Zuckerkandl, B. Die Klimt-Affäre anläßlich der Zurückziehung der Universitätsbilder (12. Apri 1905). In Zeitkunst Wien 1901-1907 (mit einem Geleitwort von Ludwig Hevesi), pp. 165-166. Wien Heller.

23. Guth, D. 2005. "This is not a sign of the times it's a sign of extravagance." The scandal surrounding Gustav Klimt's faculty paintings. In Die nackte Wahrheit. Klimt, Schiele, Kokoska und andere Skandale. (Tobias G. Natter and Hans Holein, eds.) Munich Presetl. P. 67-75, p. 70

24. Zuckerkandl, B. Österreich intim. Erinnerun gen 1892-1942 (ed. by Reinhard Federmann). Frankfurt/M: Propyläen (1970).

25. Anon. Zentralblatt für Volksbildungswesen. $V i$ erter Jahresbericht des Vereins "Volksheim" in Wien über seine Tätigkeit von Ostern 1904 bis Ostern 1905. Leipzig. Teubner. pp. 1, 8 (1905).

26. See Zuckerkandl [24] pp. 133-134.

27. Reiter, W.L. Zerstört und vergessen: Die biologische Versuchsanstalt und ihre Wissenschaftler innen. OZZG 10, 585-614 (1999).

28. Lesky [16].

29. Gliboff, S. "Protoplasm . . . is soft wax in our hands": Paul Kammerer and the art of biological transformation. Endeavour 29, 162-167 (2005)

30. Przibram, H. Illustrationen. In Die Narrenlaufbah by Karl Friedrich Heitmann. Ver Sacrum 4, 183-198 (1901)

31. Gliboff [29].

32. Celenza, Anna H. (2010). Darwinian Vision Beethoven Reception in Mahler's Vienna. The Musical Ouarterly (advanced online publication, Feb. 25, 2010).

33. Przibram, H. Embryogenese. Eine Zusammenfassung der durch Driesch's Versuche ermittelten Gesetzmäßigkeite der durch Driesch's Versuche ermittelten Gesetzmäßigkeiten tierischer Ei-Entwicklung (Befruchtung, Furchu
ganbildung). Wien: Franz Deuticke (1907).

34. Lindsley, R. 1994. Utopia will not be televised: Rivera at Rockefeller Center. Oxford Art Journal 17: $48-62$.

35. Rivera, D. My Art, My Life: An Autobiography [by] Diego Rivera (with Gladys March) New York: Citade Diego Rivera

36. Wolfe, B.D. 1963. The Fabulous Life of Diego Rivera. New York: Stein and Day.

37. For instance, Taylor, G.R. 1963 The Science of Life A Picture History of Biology. Thames and Hudson, London.

38. Rivera's interest in anatomy was apparently flamed by his visit to the Parisian surgical clinic of the gynecologist and textbook author Jean Loui the gynecologist and textbook author Jean Louis Fauré in 1920. Dividing cells also appear in Rivera's
Detroit murals and in the 1940 painting, The Hands of Detroit murals and in the 1940 painting, The Hands of
Dr.Moore. See Toledo-Pereyra, L. 2007. Diego Rivera and his extraordinary art of medicine and surgery. Journal of Investigative Surgery 20: 139-143.

39. Patten, B. 1931. Embryology of the Pig (Second Ed.) New York: Maple Press (p. 16)
40. Patten, B. 1946. Human Embryology. Philadelphia: Blakiston. p. 22.

41. Encyclopedia Brittanica, 2007, <www.britannica.com/EBchecked/topic-art/435788/99761/ The-steps-of-ovulation-beginning-with-a-dormantprimordial-follicle>.

42. Clarke, A.E. 1998. Disciplining Reproduction: Mo dernity, American Life Sciences and the 'Problems of Sex., Berkeley: University of California Press (p. 183).

43. Trotsky, L. 1918, in Deutscher, I. 1959. The Prophet Unarmed: Trotsky, 1921-1929, Oxford University Press.

44. Trotsky, L. 1922. Literature and Revolution, available at <www.marxists.org/archive/trotsky/1924/ lit_revo/ch08.htm>.

45. Trotsky, L. 1934. If America Should Go Communist Liberty March 23, 1935. Accessible at <www. marxists.org/archive/trotsky/1934/08/ame.htm>.

46. Herrera, H. 2002. Frida: A Biography of Frida Kahlo. Harper, NY.

47. H. Bernstein, C. Black 2008. Frida Kahlo: Realistic Reproductive Images in the Early Twentieth Century, The American Journal of Medicine 121: 1114-1116.

48. Rosenzweig, D. and Rosenzweig, M. 2008. The trove in Frida's dressing room. In Rosenzweig D. and Rosenzweig, M., Self Portrait in a Velvet Dress. Chronicle Books, SF, p. 13-16; p. 13.

49. Herrera [46] p. 327

50. Harrison, C. and Wood, P. Art in Theory, 19002000: An Anthology of Changing Ideas. Wiley-Blackwell, NY. pp. 649-652.

51. Kahlo, F. 1945. "Speaking of one of my paintings, or how, starting from a suggestion by José D. Lavín and a text by Freud, I made a picture of Moses," in and a text by Freud, I made a picture of Moses," in
Tibol, R. (editor; Dechant, G., translator) 2006. Frida Tibol, R. (editor; Dechant, G., translator) 2006. Frida
by Frida. Mexico City. Editorial RM (pp. 286-291).

52. If not to put too fine a point that this is her critique of Rivera's universe, the hand-like ravs coming from the sun references Rivera's Creation, the mural that Rivera was painting when the schoolgirl Kahlo first fell in love with him.

53. Herrera [46] p. 326

54. Bakewell, L. 1993. Frida Kahlo: A Contemporary Feminist Reading. Frontiers: A Journal of Women's Stud ies 13: 165-189.

55. Kahlo, F. 1950, diary entry, cited in Herrera [46] p. 328; Harrison and Wood [50] p. 650

56. Lillie, F.R. 1919. Problems of Fertilization. University of Chicago Press, Chicago.

57. Indeed, this "universal" term is still used by scientists in this field, and one of the newest books on egg formation is called Oogenesis: The Universal Process egg formation is called Oogenesis: The Universal Process
(2010. ed. M.H. Verlac and A. Villeneuve, New York: Wiley)

58. Flannery [1]

59. Gilbert and Howes-Mischel [3]

60. Maienschein, J. From presentation to representation in E.B. Wilson's The Cell. Biology and Philosoph 6: 227-254 (1991)

61. Taylor, P.J., Blum, A.S. 1991. Pictorial representation in biology. Biology and Philosophy 6: 125-134.

62. Daston, L., Galison, P. "The image of objectivity," Representations 40: 81-128 (1992).

63. Flannery [1]

64. Larson, B. Odilon Redon and the Pasteurian Revolution: Health, Illness, and le monde invisible. Science in Context 17, 503-424 (2004).

65. Barnett, V.E. Kandinsky and science: The introduction of biological images in the Paris period. In 
Kandinsky in Paris (1934-1944). Exh. cat. (Christian Deronet, ed), pp. 61-87. New York: Solomon R. Guggenheim Foundation (1985)

66. Green, L. "There's a protozoan in that painting." BioScience 37, 181-185 (1987).

67. Slatkin, W. Maternity and sexuality in the 1890 s. Woman's Art Journal 1: 13-19 (1980).

68. Biology and Gender Study Group. The importance of feminist critique for contemporary cell biology. Hypatia 3: 61-76. (1988).

69. Gilbert, S.F. and Biology and Gender Study Group. Mainstreaming feminist critique into the biology curriculum. In R. Reid and S. Traweek, eds., Doing Science + Culture. Routledge, NY. 2000. pp. 199-220.

70. Martin, E.M. The egg and the sperm: How science has constructed a romance based on stereotypical male-female roles. Signs 16: 485-501 (1991).
71. Coomaraswamy, A. 1956. The Transformation of Nature in Art. Dover, NY.

72. Kemp, M. 1996. Doing what comes naturally: Morphogenesis and the limits of the genetic code Art Journal 55: 27-32.

73. Gilbert [11], pp. 348-351.

74. Dean [6].

75. From Ducibella, T., Albertini, D.F., Anderson, E. Biggers, J.D. 1975. The preimplantation mammalian embryo: characterization of intercellular junction and their appearance during development. Developmental Biology 45 (2): 231-250 and Gilbert [11]

76. From Strumpf, D., Mao, C.A., Yamanaka, Y. Ralston, A., Chawengsaksophak, K., Beck, F., Rossant, J. 2005. Cdx2 is required for correct cell fate specification and differentiation of trophectoderm in the mouse blastocyst. Development 132(9): 2093-2102 and Gilbert [11].
Manuscript received 10 May 2010.

Scott F. Gilbert is a developmental biologist and textbook author. His research includes analyzing the roles of development in evolution and studying the ways that critical theory can be applied to the sciences.

Sabine Brauckmann is head of the Science Studies of the Life Sciences Group at University of Tartu, where she conducts research on the history of embryology, the visual history of cell biology, and on "plant spaces" (herbaria, gardens, research centers) of the 19th century. She has organized numerous symposia on these topics.

\section{JOIN US}

\section{Become a Leonardo Affiliate!}

Now you can join a distinctive group of non-profit organizations, educational institutions and innovative corporations working in the realms of art, science and technology by becoming an organizational Affiliate Member of Leonardo.

You and your organization will gain access to a full spectrum of opportunities offered exclusively to our Affiliate Members, including:

- Enhanced networking with peers in a dynamic, interdisciplinary community

- Opportunities for collaboration

- Invitations to participate in exhibitions, panels and workshops

- New options to increase visibility for your organization or company

- Discounts on advertisements, subscriptions and more!

To view the current member list, membership levels and benefits, and to join the program, visit $<$ www.leonardo.info/isast/org-membership.html>. 